\title{
Atlantic Standard Time
}

National Cancer Institute

\section{Source}

National Cancer Institute. Atlantic Standard Time. NCI Thesaurus. Code C116263.

Local standard time, based at the 60th meridian west of the Greenwich Observatory, established as four hours behind Coordinated Universal T ime. 